\title{
Importance of cytomatrix-bound polysomes to synthesis of lysine-containing proteins in triticale germs under ABA treatment
}

\author{
Ewa Szypulska $\cdot$ Stanisław Weidner
}

Received: 29 March 2010/Revised: 16 November 2010/ Accepted: 17 November 2010/Published online: 20 January 2011

(C) The Author(s) 2011. This article is published with open access at Springerlink.com

\begin{abstract}
The influence of exogenous abscisic acid (ABA) on the content of free polysomes (FP), membranebound polysomes (MBP), cytoskeleton-bound polysomes (CBP) and cytomatrix-bound polysomes (CMBP) in triticale germs as well as in vitro protein synthesis by these four polysomal fractions were studied. During translation, proteins were biotinylated for chemiluminescence detection. We have found that ABA changed both the content of FP, MBP, CMP and CMBP in germ tissue, and their subsequent translation activity. At $100 \mu \mathrm{M}$ ABA, the content of FP and MBP was over fourfold lower compared to the control, whereas the amounts of CBP and CMBP were about two- and threefold higher, respectively. Moreover, the estimation of the share of polysomes in each ribosomal fraction (sub-units, monosomes, polysomes) showed that, at $100 \mu \mathrm{M}$ ABA, cytomatrix-bound polysomes, which constituted $90 \%$ of polysomes, were the predominant class in ABA-treated germs while membrane-bound polysomes, which made up $82 \%$ of polysomes, dominated in the control. A high level of CMBP in ABA-treated tissues may indicate that this class of polysomes participates in ABAinduced synthesis of proteins. In turn, the inhibition of MBP under ABA-treatment is probably due to the delayed protein synthesis which takes place on these polysomes. We identified two lysine-containing proteins synthesized on both of the above classes of polysomes, whose synthesis was altered due to ABA application. Synthesis of a $47 \mathrm{kDa}$
\end{abstract}

Communicated by S. Abe.

E. Szypulska $(\bowtie) \cdot S$. Weidner

Department of Biochemistry, Faculty of Biology,

University of Warmia and Mazury in Olsztyn,

M. Oczapowskiego St., 1A, 10-957 Olsztyn-Kortowo, Poland

e-mail: ewa.fraczek@uwm.edu.pl protein on MBP was inhibited, while synthesis of a $79 \mathrm{kDa}$ protein on CMBP is strongly enhanced by ABA influence. The importance of these findings is discussed.

Keywords Abscisic acid - Cytomatrix-bound polysomes · Germination · Lysine-containing proteins · Triticale caryopses

$\begin{array}{ll}\text { Abbreviations } \\ \text { ABA } & \begin{array}{l}\text { Abscisic acid } \\ \text { CBP }\end{array} \\ \text { CMBP } & \begin{array}{l}\text { Cytoskeleton-bound polysomes } \\ \text { (cytomatrix-bound polysomes) }\end{array} \\ \text { EGTA } & \text { Ethylene glycol-bis ( } \beta \text {-aminoethyl ether)- } \\ & N, N, N^{\prime}, N^{\prime} \text {-tetraacetic acid } \\ \text { FP } & \text { Free polysomes } \\ \text { HEPES } & N \text {-2-hydroxyethylpiperazine- } \\ & N^{\prime} 2^{\prime} \text { ethanesulfonic acid } \\ \text { KOAc } & \text { Potassium acetate } \\ \text { Luc } & \text { Luciferase } \\ \text { MBP } & \text { Membrane-bound polysomes } \\ \text { Mg }(\mathrm{OAc})_{2} & \text { Magnesium acetate } \\ \text { PMSF } & \text { Phenylmethylsulfonyl fluoride } \\ \text { PTE } & \text { Polyoxyethylene-10-tridecyl ether } \\ \text { Tris } & \text { Tris-(hydroxymethyl) aminomethane }\end{array}$

\section{Introduction}

Along with other regulators of plant growth and development, ABA plays a major role in the control of embryo maturation and seed formation via regulation of storage reserve deposition, acquisition of desiccation tolerance as 
well as induction of primary dormancy and suppression of precocious germination (Still et al. 1994; Bartels et al. 1988; Gerjets et al. 2010). Although more research dealing with mechanisms of ABA action has been conducted, many questions remain unanswered. It is well known that ABA affects the induction of genes for some specific proteins (Still et al. 1994; Mukherjee et al. 2006; Cao et al. 2007; Xiang et al. 2008) and the inhibition of certain reserve mobilizing enzymes (Robertson et al. 1989; Gómez-Cadenas et al. 1999, 2001; Bethke et al. 2006). Some studies show that ABA also has the ability to modify the orientation of microtubules, a cytoskeletal element directing mRNA transport and localization, which may lead to the alteration of targeted synthesis of proteins within the cell (Shibaoka 1994; Klyachko 2003). Furthermore, ABA may also elicit changes in the process of polysome formation, an event essential for protein synthesis (Weidner et al. 2003). Polysomes consist of two or more ribosomes on an mRNA strand and their formation takes place in different cell compartments. In addition to the two common types: free polysomes (FP) and membrane-bound polysomes (MBP), there is a wealth of evidence suggesting that both cytoskeleton-bound (CBP) and cytoskeleton-membrane bound (cytomatrix-bound) polysomes (CMBP) exist in plant cells (Davies and Abe 1995; Abe et al. 2003). It is proposed that the different types of polysomes are responsible for synthesis of various kinds of proteins. FP are thought to be involved primarily in the synthesis of cytosolic proteins, $\mathrm{MBP}$-secreted, sequestered and membrane proteins, $\mathrm{CBP}$-cytoskeletal, viral or stress proteins (Krupińska et al. 2003). There are also some studies indicating that CMBP is involved in storage protein synthesis (Stanković et al. 1993; Abe et al. 2003).

The aim of the study was to estimate the influence of ABA on FP, MBP, CBP and CMBP formation as well as identification of newly formed proteins, synthesized by these four populations of polysomes. Williamson and Quatrano (1988) suggested that effects of exogenous ABA on embryo-specific gene expression in mature grain embryos, 1-2 days postimbibition, is comparable to the effects of ABA on immature embryos. Therefore, all experiments were conducted after $48 \mathrm{~h}$ exposure of triticale caryopses to ABA treatment.

\section{Materials and methods}

Plant material and germination conditions

The experiments were conducted on cv. Ugo triticale (Triticosecale) caryopses, supplied by the Plant Cultivation Station in Strzelce. Seeds were surface disinfected in $0.5 \%$ sodium hypochlorite for $20 \mathrm{~min}$ and washed with sterilized water. Twenty intact grains were placed on two layers of Whatman paper no 1 (Whatman, Maidstone, Kent, the UK) in a Petri dish $(\varnothing 9 \mathrm{~cm})$ containing $15 \mathrm{ml}$ solutions of abscisic acid (10 or $100 \mu \mathrm{M})$ and incubated for $48 \mathrm{~h}$ in the darkness at $20^{\circ} \mathrm{C}$. Grains were scored as germinated when the radicle was $\geq 1 \mathrm{~mm}$ long. In addition, some seeds were also germinated in distilled water for comparison with tested samples. Dry weight was determined by placing $200 \mathrm{mg}$ of fresh weight of embryos/germs in an oven at $105^{\circ} \mathrm{C}$ for $24 \mathrm{~h}$.

Polysome isolation and quantification

The cytoskeleton-stabilizing buffer $\mathrm{C}$ (Abe and Davies 1991), consisting of $5 \mathrm{mM}$ HEPES, $10 \mathrm{mM} \mathrm{Mg}(\mathrm{OAc})_{2}$, $2 \mathrm{mM}$ EGTA, $1 \mathrm{mM}$ PMSF adjusted to $\mathrm{pH} 7.5$ with $9.8 \mathrm{mM} \mathrm{KOH}$, was used for isolation of cytoskeleton fractions from triticale germs after $48 \mathrm{~h}$ of caryopses germination. This buffer allows sequential isolation of four polysome populations (Davies and Abe 1995): FP (free polysomes), MBP (membrane-bound polysomes), CBP (cytoskeleton-bound polysomes) and CMBP (cytoskeletonmembrane-bound polysomes). All the fractions were layered on a $0.5 \mathrm{ml}$ "pad" of $50 \%$ (w/v) sucrose in buffer B (50 mM Tris-HCl, pH 7.5; $20 \mathrm{mM} \mathrm{KOAc,} 10 \mathrm{mM}$ $\mathrm{Mg}(\mathrm{OAc})_{2}$ and centrifuged for $1.5 \mathrm{~h}$ at $300,000 \mathrm{~g}$ in a Beckman SW 55 Ti Rotor. The polysomal pellets were rinsed in water and then resuspended in $350 \mu \mathrm{l}$ of $0.5 \%$ PTE. The resuspended polysomes were centrifuged at top speed (approximately 18,000g) for $2 \mathrm{~min}$ in a microfuge prior to layering $0.2 \mathrm{ml}$ aliquots (about $15 \mathrm{OD}$ units) on linear $15-60 \%(\mathrm{w} / \mathrm{v})$ sucrose gradients in buffer B and centrifuged at 300,000 $\mathrm{g}$ in a Beckman SW 55 Ti Rotor for $45 \mathrm{~min}$. The gradients were subsequently scanned at $254 \mathrm{~nm}$ on a UA-5 flow recorder (ISCO, Lincoln, NE, USA) to display subunits, monosomes and polysomes. All the operations were conducted at $0-4^{\circ} \mathrm{C}$. More details of the methods applied were described in an earlier paper (Weidner et al. 2003). Levels of polysomes were determined by measuring the area under the polysomal profile after subtracting the gradient baseline OD (absorbance of the gradient loaded with $0.2 \mathrm{ml}$ of resuspension buffer). Quantitation of the ribosomes was done assuming that the absorbance of a $1 \%$ solution of ribosomes (measured in a cuvette with a $1 \mathrm{~cm}$ optical path at $260 \mathrm{~nm}$ ) equals 135 (Gualerzi and Cammarano 1969).

In vitro translation with incorporation of biotinylated lysisne

Protein synthesis on different polysomal fractions (FP, $\mathrm{MBP}, \mathrm{CBP}$ and CMBP) was conducted in nuclease-treated rabbit reticulocyte lysate using biotin-Lys-tRNA ${ }^{\text {Lys }}$ plus 
the remaining amino acids mix (Promega). Following the isolation of polysomes, 1.5 OD units of each polysomal fraction were added per $50 \mu \mathrm{l}$ of total reaction mixture. After incubation at $30^{\circ} \mathrm{C}$ for $90 \mathrm{~min}$, the mixtures were placed on ice to stop the reaction. Additionally, two control reactions were performed containing: (1) no RNA (to exclude any background) and (2) the $1 \mu \mathrm{g}$ of luciferase RNA (to test synthesis of lysine-rich luciferase). Luciferase control was added to sample reactions in order to estimate the regularity of conducted translation.

Detection of newly synthesized proteins

by western-blotting and chemiluminescence

After in vitro translation, $1 \mu \mathrm{l}$ aliquot from the each $50 \mu \mathrm{l}$ translation reaction was mixed with $15 \mu \mathrm{l}$ of SDS sample buffer. After denaturation, biotinylated proteins were separated in $12 \%$ SDS-polyacrylamide gel (SDS-PAGE) according to Laemmli (1970), transferred to polyvinylidene difluoride membrane (PVDF, Osmonics), and visualized by binding Streptavidin-HRP, followed by chemiluminescent detection (Transcend ${ }^{\mathrm{TM}}$ Chemiluminescent Translation Detection System, Promega). To determine the apparent weight of the translated biotinylated proteins, biotinylated protein standards (Bio-Rad) were used.

\section{Results}

Four fractions of polysomes: FP, MBP, CBP and CMBP from triticale germs were isolated after $48 \mathrm{~h}$ inhibition of seed germination induced by 10 or $100 \mu \mathrm{M}$ ABA. Polysomes were successively isolated by using buffer $\mathrm{C}$ and its derivates, which stabilized the cytoskeleton. Changes in contents of these populations in gram of tissue dry weight under ABA treatment are shown in Fig. 1. The most abundant fraction in the examined control tissue was composed of free polysomes, whereas the smallest fraction consisted of cytomatrix-bound polysomes. A completely reverse situation was observed under ABA influence. Application of abscisic acid induced a decrease in free (FP) as well as in membrane-bound polysomes (MBP), and an increase in cytoskeleton- (CBP) and cytomatrix-bound polysomes (CMBP). Changes in the content of each polysomal fraction were ABA dose-dependent. It should be emphasized that the predominant polysome population in samples treated with 10 or $100 \mu \mathrm{M}$ ABA was CMBP, which increased over two- and threefold, respectively, versus the control.

Figure 2 shows the sedimentation profiles of particular polysomal populations in 15-60\% sucrose gradients. Percentages of polysomes in each total ribosomal fraction (subunits + monosomes + polysomes) were quantified in order to approximately estimate their translational activity.

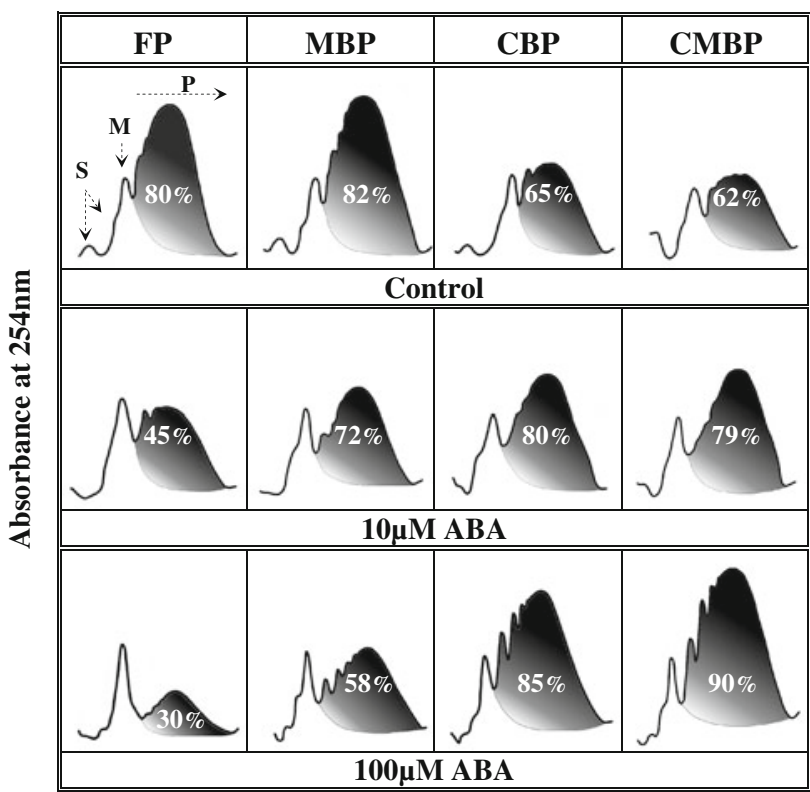

Direction of polysomes sedimentation

$$
\begin{aligned}
& \mathbf{S} \text { - subunits } \\
& \mathbf{M} \text { - monosomes } \\
& \mathbf{P} \text { - polysomes (dark areas) }
\end{aligned}
$$

Fig. 1 Effects of ABA on sub-cellular distribution of polysomes: individual profiles

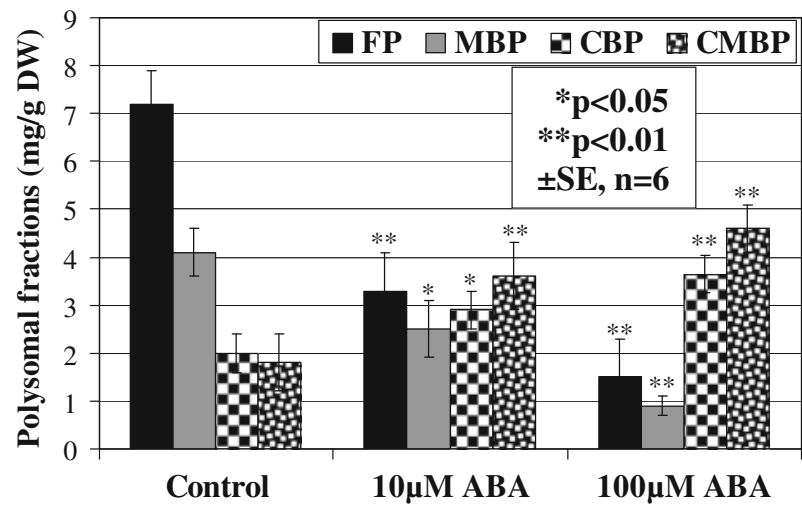

Fig. 2 Effects of ABA on sub-cellular distribution of polysomes: detailed analysis

If the rates of attachment of ribosomes (initiation), movement of ribosomes (translocation) and detachment of ribosomes (termination) are similar for different messages, the number of ribosomes per message will be proportional to its length. The proportion of ribosomes from control tissue existing as polysomes was differential and ranged $62-80 \%$ in the four fractions. At 10 and $100 \mu \mathrm{M} \mathrm{ABA}$, the percentage of FP was greatly reduced, from 80 to 45 and $30 \%$, respectively. Similarly, the share of MBP was also lower, decreasing from 82 to 72 and $58 \%$ in an ABA dosedependent way. In contrast, the share of both CBP and 


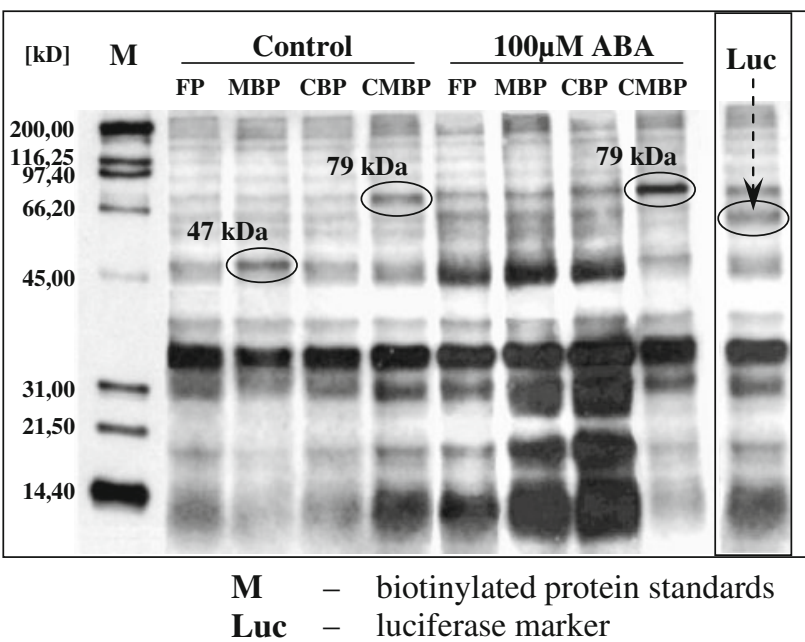

Fig. 3 Effects of prior treatment with $\mathrm{ABA}$ on in vitro synthesis of lysine-containing proteins by different classes of polysomes

CMBP increased under $\mathrm{ABA}$ treatment. $\mathrm{CBP}$ and $\mathrm{CMBP}$ reached only about $63 \%$ in the control, increasing significantly under the influence of 10 and $100 \mu \mathrm{M}$ ABA to about 80 and $87 \%$, respectively.

We then checked if there were any differences between FP, MBP, CBP and CMBP in protein synthesis under $100 \mu \mathrm{M}$ ABA treatments. Western-blotting of biotinylated, lysine-containing proteins, synthesized in vitro on four polysomal fractions from the control and ABA-treated tissue is presented in Fig. 3. Two changes in newly synthesized proteins compared to the control were observed. Differences induced by ABA were noticed in protein synthesis on two different polysomal fractions, MBP and CMBP, being quantitative rather than qualitative. Two completely opposite results between protein synthesis on MBP and CMBP under ABA influence were observed. On the one hand, $A B A$ inhibited synthesis of a $47 \mathrm{kDa}$ protein on MBP but on the other hand, strongly induced a $79 \mathrm{kDa}$ protein synthesis on CMBP.

\section{Discussion}

In this study, we have investigated which fraction of polysomes was involved in the protein synthesis under the influence of exogenous ABA. It was demonstrated that the application of $\mathrm{ABA}$ during triticale germination induced the largest increase in the cytomatrix-bound polysomes content. If we assume that CMBP is involved in the synthesis of storage proteins, it is possible that ABA could induce genes responsible for the synthesis of these proteins on cytomatrix-bound polysomes.
It is well known that ABA plays a role in promoting the synthesis of storage proteins in cereal seeds, including the most common ones such as globulins (for example GLB1 globulin in maize embryos) and lectin wheat-germ agglutinin (WGA) (Raikhel and Quatrano 1986; Rivin and Grudt 1991; Shakirova et al. 2003). Another group of proteins whose synthesis is enhanced by $\mathrm{ABA}$ are late embryogenesis abundant (LEA) proteins involved in the development of desiccation tolerance in seeds. This group of hydrophilic polypeptides includes wheat $\mathrm{E}_{\mathrm{m}}$ protein, which is produced as ABA peaks during the seed development or can be induced in mature embryos and seedlings under ABA treatment (Ried and Walker-Simmons 1990).

In this study, an increase in CMBP was closely associated with the amount of synthesized $79 \mathrm{kDa}$ protein. Although cereal proteins are poor in lysine, detection of biotinylated proteins applied in this work allows identification of polypeptides containing this aminoacid. Parallel to this component of the research, we separated the proteome from triticale embryos of cv. Ugo triticale (data not shown in this paper) germinated in $100 \mu \mathrm{M}$ ABA for $48 \mathrm{~h}$ (the same conditions as in this study). Having compared the results of these two tests, we can expect that it is not a single protein, but a group of proteins which differ in the isoelectric point. The analysis we performed on a MALDI-TOF mass spectrophotometer and the search in the MASCOT database enabled us to identify three lysine-rich LEA proteins. According to these results (Badowiec et al. 2009), we suggest that LEA can be synthesized on cytomatrixbound polysomes.

On the other hand, we found that $\mathrm{ABA}$ inhibits formation of the membrane-bound polysome (MBP) and synthesis of $47 \mathrm{kDa}$ protein. Some authors suggest that MBP is responsible for synthesis of secreted, sequestered and membrane proteins. It is also well documented that among ABA-inducible proteins there is barley $\alpha$-amylase inhibitor involved in blocking precocious germination by interference with $\alpha$-amylase activity (Robertson et al. 1989). We noticed that the synthesis of $47 \mathrm{kDa}$ protein in the control sample was the most intensive on the MBP fraction, whereas the application of ABA inhibits synthesis of this protein. Based on the other research we conducted at the same time, we can suggest that the protein obtained is like a lysine-rich ATP synthetase beta subunit (Badowiec et al. 2009). We can suppose that ABA inhibits the enzymatic activity in embryos also by retarding MBP formation. In this study, we found that ABA has a direct inhibitory influence on enzyme synthesis, which is distinguished from the indirect inhibition of $\alpha$-amylase activity. 
Open Access This article is distributed under the terms of the Creative Commons Attribution Noncommercial License which permits any noncommercial use, distribution, and reproduction in any medium, provided the original author(s) and source are credited.

\section{References}

Abe S, Davies E (1991) Isolation of F-actin from pea stems: Evidence from fluorescence microscopy. Protoplasma 163:51-61

Abe S, Azama K, Sugimoto H, Davies E (2003) Protein accumulation in the maize endosperm: role of polyribosomes and the cytoskeleton. Plant Physiol Biochem 41:125-131

Badowiec A, Świgońska S, Szypulska E, Weidner S (2009) Influence of exogenous abscisic acid on alterations in protein expression in the proteome of Triticosecale seedlings. Viterbo 2009-COST FA0603-WG1 Meeting. Technical aspects inherent to Plant Proteomics. "Classical and novel approaches in Plant Proteomics", p 44

Bartels D, Singh M, Salamini F (1988) Onset of desiccation tolerance during development of the barley embryo. Planta 175:485-492

Bethke PC, Hwang Y, Zhu T, Jones RL (2006) Global patterns of gene expression in the aleurone of wild-type and dwarf1 mutant rice. Plant Physiol 140:484-498

Cao X, Costa LM, Biderre-Petit C, Kbhaya B, Dey N, Perez P, McCarty DR, Gutierrez-Marcos JF, Becraft PW (2007) Abscisic acid and stress signals induce viviparous 1 expression in seed and vegetative tissues of maize. Plant Physiol 143:720-731

Davies E, Abe S (1995) Method for isolation and analysis of polyribosomes. Methods Cell Biol 50:209-222

Gerjets T, Scholefield D, Foulkes MJ, Lenton JR, Holdsworth MJ (2010) An analysis of dormancy, ABA responsiveness, afterripening and pre-harvest sprouting in hexaploid wheat (Triticum aestivum L.) caryopses. J Exp Bot 61:597-607

Gómez-Cadenas A, Verhey SD, Holappa LD, Shen Q, Ho THD, Walker-Simmons MK (1999) An abscisic acid-induced protein kinase, PKABA1, mediates abscisic acid-suppressed gene expression in barley aleurone layers. Proc Natl Acad Sci USA 96:1767-1772

Gómez-Cadenas A, Zentella R, Walker-Simmons MK, Ho THD (2001) Gibberellin/abscisic acid antagonism in barley aleurone cells: site of action of the protein kinase PKABA1 in relation to gibberellin signaling molecules. Plant Cell 13:667-679

Gualerzi C, Cammarano P (1969) Comparative electrophoretic studies on the protein of chloroplast and cytoplasmic ribosomes of spinach leaves. Biochim Biophys Acta 190:170-186

Klyachko NL (2003) Phytohormones and cytoskeleton. Russian J Plant Physiol 50:426-430
Krupińska S, Weidner S, Frączek E, Amarowicz R (2003) Polysome formation and stability in pea stem and root tissue. Acta Physiol Plant 25:135-141

Laemmli UK (1970) Cleavage of structural proteins during the assembly of the head of bacteriophage T4. Nature 227:680-685

Mukherjee K, Choudhury AR, Gupta B, Gupta S, Sengupta DN (2006) An ABRE-binding factor, OSBZ8, is highly expressed in salt tolerant cultivars than in salt sensitive cultivars of indica rice. BMC Plant Biol 6:18

Raikhel NV, Quatrano RS (1986) Localization of wheat-germ agglutinin in developing wheat embryos and those cultured in abscisic acid. Planta 168:433-440

Ried JL, Walker-Simmons MK (1990) Synthesis of abscisic acidresponsive, heat-stable proteins in embryonic axes of dormant wheat grain. Plant Physiol 93:662-667

Rivin CJ, Grudt T (1991) Abscisic acid and the developmental regulation of embryo storage proteins in maize. Plant Physiol 95:358-365

Robertson M, Walker-Simmons M, Munro D, Hill RD (1989) Induction of $\alpha$-amylase inhibitor synthesis in barley embryos and young seedlings by abscisic acid and dehydration stress. Plant Physiol 91:415-420

Shakirova FM, Bezrukova MV, Aval'baev AM, Fatkhutdinova RA (2003) Control mechanisms of lectin accumulation in wheat seedlings under salinity. Russian J Plant Physiol 50:301-304

Shibaoka H (1994) Plant hormone-induced changes in the orientation of cortical microtubules: alterations in the cross-linking between microtubules and the plasma membrane. Annu Rev Plant Physiol Plant Mol Biol 45:527-544

Stanković B, Abe S, Davies E (1993) Co-localization of polysomes, cytoskeleton, and membranes with protein bodies from corn endosperm. Evidence from fluorescence microscopy. Protoplasma 177:66-72

Still DW, Kovach DA, Bradford KJ (1994) Development of desiccation tolerance during embryogenesis in rice (Oryza sativa) and wild rice (Zizania palustris) (dehydrin expression, abscisic acid content, and sucrose accumulation). Plant Physiol 104:431-438

Weidner S, Frączek E, Romanowska M, Amarowicz R, Abe S, Davies E (2003) The influence of abscisic acid on different polysomal populations in embryonal tissue during pea seeds germination. Acta Physiol Plant 25:5-12

Williamson JD, Quatrano RS (1988) ABA-regulation of two classes of embryo-specific sequences in mature wheat embryos. Plant Physiol 86:208-215

Xiang Y, Tang N, Du H, Ye H, Xiong L (2008) Characterization of OsbZIP23 as a key player of the basic leucine zipper transcription factor family for conferring abscisic acid sensitivity and salinity and drought tolerance in rice. Plant Physiol 148:1938-1952 